\section{Peningkatan Hasil Belajar IPA melalui Model Pembelajaran Iqro' dengan Berbantuan Media Video pada Siswa Kelas VII A SMP Negeri 2 Amali Kabupaten Bone}

\author{
Sri Wahyuni \\ Lita Citra
}

\begin{abstract}
Abstrak. Penelitian ini adalah penelitian tindakan kelas (PTK) yang bertujuan untuk meningkatkan hasil belajar IPA siswa kelas VII A, melalui model pembelajaran Iqro' dengan berbantuan media video di SMP Negeri 2 Amali Kabupaten Bone. Subjek penelitian berjumlah 18 siswa kelas VII A SMP Negeri 2 Amali yang terdiri dari 10 laki-laki dan 8 perempuan pada semester genap tahun pelajaran 2018/2019. Penelitian ini dilaksanakan dalam dua siklus dengan enam kali pertemuan. Pengambilan data hasil belajar siswa dilakukan pada tiap akhir siklus. Teknik pengumpulan data pada penelitian ini menggunakan instrument berupa tes hasil belajar dalam bentuk pilihan ganda berjumlah 25 nomor. Data yang diperoleh, dianalisis dengan menggunakan analisis statistik deskriptif. Hasil analisis data menunjukkan bahwa rata-rata nilai hasil belajar siswa meningkat dari 70,78 pada akhir siklus I menjadi 85,11 pada siklus II. Ketuntasan hasil belajar siswa pada akhir siklus I 61,11\% dan mencapai 88,89 \% pada siklus II. Disimpulkan bahwa model pembelajaran Iqro' berbantuan media video meningkatkan hasil belajar biologi siswa kelas VII A SMP Negeri 2 Amali Kabupaten Bone.

Keywords: model pembelajaran iqro', media video, hasil belajar
\end{abstract}

\section{Pendahuluan}

Sistem pendidikan di Indonesia saat ini telah menjadikan kurikulum 2013 sebagai patokan dasar dalam menjalankan proses pembelajaran. Kurikulum 2013 dinilai mampu memberikan peningkatan kualitas pendidikan dan moral serta keagamaan bagi siswa-siswi disekolah dalam setiap materi pada semua mata pelajaran, salah satunya yaitu pada mata pelajaran IPA. Pendidikan nasional bertujuan untuk mengembangkan potensi peserta didik agar menjadi manusia yang beriman dan bertaqwa kepada Tuhan Yang Maha Esa, berahlak mulia, sehat, berilmu, cakap, kreatif, mandiri, serta bertanggung jawab. Kegiatan yang paling mendasar dalam dunia pendidikan adalah kegiatan belajar mengajar yang nantinya akan sangat menentukan tingkat keberhasilan dalam pencapaian tujuan pembelajaran. Pemilihan model pembelajaran merupakan salah satu kunci dalam memberikan pengaruh yang positif pada minat belajar siswa yang tentu akan meningkatkan hasil belajar siswa. Selain itu, pemilihan model pembelajaran yang tepat, dapat memberikan suasana belajar yang lebih menarik dan kondusif, serta memberikan dampak pada pola belajar siswa di kelas agar siswa lebih fokus. Ilmu Pengetahuan Alam (IPA) Terpadu pada tingkat SMP/sederajat merupakan salah satu mata pelajaran yang mengaitkan antara satu bidang ilmu dengan ilmu lainnya

\section{Biology Teaching and Learning}

p-ISSN $2621-5527$

e-ISSN 2621 - 5535

Abstract. This research is a classroom action research that aims to improve the students' learning outcomes of IPA in class VII A, through the Iqro' learning model with support of video media in SMP Negeri 2 Amali at Bone regency. Subject of this research consisted of 18 students of class VII A of SMP Negeri 2

Amali consisting of 10 men and 8 women in the second semester of the 2018/2019 academic year. This research was conducted in two cycles with six meetings. The data retrieval of students' learning outcomes is done in the end of every cycle. Technique of data collection in this research used instrument in the form of a test of learning outcomes in the form of multiple choice consist 25 numbers. The data obtained were analyzed using descriptive statistical analysis. The result of data analysis showed that the average value of students learning outcomes increase from 70,78 in the end of cycle I increase to 85,11 in cycle II. The completeness of students' learning outcomes in the end of cycle I $61,11 \%$ and become 88,89 in cycle II. It can be conclude that the Iqro' learning model with video media improve the students' learning outcomes of IPA in class VII A SMP Negeri 2 Amali at Bone regency.

Keywords: iqro' learning model, video media, learning outcomes

Sri Wahyuni

STKIP Muhammadiyah Bone Indonesia

Lita Citra

STKIP Muhammadiyah Bone Indonesia 
sehingga dalam proses pembelajaran tenaga pengajar seharusnya memadukan materi tersebut menjadi satu kesatuan agar tidak nampak terpisah-pisah sesuai dengan apa yang dipahami oleh masyarakat luas. Oleh karena, itu diperlukan kemampuan seorang guru untuk memilih model atau strategi yang sesuai dengan materi agar tercipta pembelajaran yang efektif. Proses pembelajaran yang efektif yakni dengan membentuk komunikasi dua arah sehingga peserta didik bisa memahami dan lebih aktif dalam pembelajaran. Dalam proses komunikasi sering timbul dan terjadi penyimpangan-penyimpangan yang menyebabkan proses belajar mengajar tidak efektif dan efisien, antara lain disebabkan oleh adanya, ketidaksiapan siswa, kurang minat dan motivasi, sehingga menyebabkan siswa tidak fokus terhadap materi yang disampaikan guru. Salah satu faktor yang mempengaruhi keberhasilan guru dalam melaksanakan pembelajaran yaitu dengan menguasi teknik-teknik pembelajaran yang dapat dipadukan dengan model pembelajaran yang sering digunakan dalam kegiatan belajar mengajar dikelas. Pemilihan teknik pembelajaran yang tepat mampu memberikan suasana belajar mengajar yang kondusif serta memberikan pengaruh yang positif terhadap hasil belajar siswa. Selain dari faktor model pembelajaran, ketepatan pemilihan media pembelajaran juga mempengaruhi keberhasilan model pembelajaran.

Pada proses pembelajaran ada masih ditemukan siswa yang tidak dapat meraih hasil belajar yang setara dengan kemampuan inteligensinya. Beberapa siswa yang mempunyai kemampuan inteligensi tinggi tetapi memperoleh prestasi belajar yang relatif rendah, namun ada siswa yang walaupun kemampuan inteligensinya relatif rendah, dapat meraih hasil belajar yang relatif tinggi. Oleh karena itu, taraf inteligensi bukan merupakan satu-satunya faktor yang menentukan keberhasilan seseorang, karena ada faktor lain yang mempengaruhi. Solusi untuk mengatasi permasalahan yang ada, diperlukan suatu alternatif, dengan menggunakan model pembelajaran yang tepat dan menarik. Model pembelajaran yang tidak hanya memberi materi pelajaran semata, namun dapat meningkatkan hasil belajar siswa dan demi tercapainya tujuan pendidikan nasional.

Penggunaan model pembelajaran yang tepat dapat dipadukan dengan media dalam menyampaikan materi pembelajaran, terkhusus pada pembelajaran IPA di SMP sangat mempengaruhi proses dan hasil belajar siswa. Banyak model-model pembelajaran yang mampu meningkatkan hasil belajar siswa jika digunakan dengan tepat, namun ada pula model pembelajaran yang justru menurunkan hasil belajar siswa, dengan kata lain bahwa model tersebut kurang efektif digunakan dalam materi pembelajaran. Dengan demikian, guru harus lebih inovatif dan jeli dalam memilih model pembelajaran yang tepat untuk suatu materi dalam mata pelajaran di sekolah.

Dalam hal ini dapat diupayakan dengan penerapan model pembelajaran yang sesuai yang dipadukan dengan media pembelajaaran yang tepat. Model pembelajaran iqro' yang dipadukan dengan media video adalah salah satu model pembelajaran dan media pembelajaran yang dapat digunakan. Model iqro' adalah suatu model pembelajaran yang mengajak siswa untuk aktif mengeksplorasi lingkungan yang ada di sekitar siswa. Siswa diajak untuk aktif berkegiatan misalnya berfikir, merenung, berdiskusi, mengamati (Setyaningrum, 2007). Selain dari faktor model pembelajaran, ketepatan pemilihan media pembelajaran juga mempengaruhi keberhasilan model pembelajaran. Model pembelajaran Iqro' yang berbasis pada pendekatan islami yang dipadukan dengan materi pembelajaran, diterapkan dengan penggunaan media video yang kolaborasi antara gambar dan visual yang akan meningkatkan tingkat keberhasilan dalam pembelajaran siswa yang tepat pada sasaran untuk mencapai tujuan pembelajaran dengan demikian, komunikasi pembelajaran dalam kelas antara guru dan siswa lebih aktif.

Model pembelajaran Iqro' yang berbasis pada pendekatan islami yang dipadukan dengan materi pembelajaran, diterapkan dengan penggunaan media video yang kolaborasi antara gambar dan visual yang akan meningkatkan tingkat keberhasilan dalam pembelajaran siswa, dengan demikian komunikasi pembelajaran dalam kelas antara guru dan siswa lebih 
Peningkatan Hasil Belajar IPA melalui Model Pembelajaran Iqro'

dengan Berbantuan Media Video pada Siswa Kelas VII A SMP

p-ISSN 2621-5527

Negeri 2 Amali Kabupaten Bone

e-ISSN 2621-5535

(hlm. 124-133)

aktif. Menurut Mayer (2012), menjelaskan bahwa media pembelajaran berbasis gambar bergerak (animasi/video) dapat mendorong pemahaman peserta didik bila digunakan dengan cara yang konsisten dengan teori pembelajaran multimedia. Pernyataan tersebut menjelaskan bahwa manusia adalah spesies visual, manusia lebih mudah mencerna informasi yang berbasis gambar.

Hal senada disampaikan oleh Sutiani (2010), yang menyatakan siswa memberikan respon dan partisipasi yang sangat baik pada saat berlangsungnya pembelajaran yang menerapkan pengitegrasian nilai agama dalam pembelajaran IPA khususnya materi terkait biologi. Menurut Karyani (2007), model pembelajaran Iqro' dapat meningkatkan pemahaman siswa terhadap materi IPA khususnya mengenai biologi. Proses uji coba pembelajaran secara terintegrasi IPTEK dan IMTAQ dapat mengubah perolehan pengetahuan dan penguasaan materi oleh siswa dengan sangat bermakna.

Video sebagai media pembelajaran sudah cukup marak digunakan dalam pembelajaran. Media video pembelajaran dapat digologkan kedalam jenis media Audio Visual Aids (AVA) atau media yang dapat dilihat atau didengar. Media audio motion visual (media audio visual gerak) yakni media yang mempunyai suara, ada gerakan dan bentuk obyeknya dapat dilihat, media ini lengkap. Informasi yang disajikan melalui media ini berbentuk dokumen yang hidup, dapat dilihat dilayar monitor atau ketika diproyeksikan ke layar lebar melalui projector dapat didengar suaranya dan dapat dilihat gerakannya (video atau animasi). Menurut Riyana (2007), media video pembelajaran adalah media yang menyajikan audio dan visual yang berisi pesanpesan pembelajaran baik yang berisi konsep, prinsip, prosedur, teori aplikasi pengetahuan untuk membantu pemahaman terhadap suatu materi pembelajaran.

Berdasarkan hasil observasi dan wawancara pada tanggal 25 Oktober 2018 dengan guru IPA di SMP Negeri 2 Amali, terkait dengan penggunaan model pembelajaran pada materi pembelajaran IPA, dalam proses pembelajaran yang telah dilaksanakan, siswa masih terkesan pasif, beberapa siswa terlihat bosan, kurang fokus dan ada yang mengantuk serta masih ada siswa yang bercerita dengan teman sebangkunya dan membuka buku mata pelajaran lain pada saat proses pembelajaran berlangsung, dengan kata lain, beberapa siswa masih kurang memperhatikan materi pada saat pembelajaran berlangsung dari fakta-fakta berdasarkan hasil observasi dan wawancara disekolah, kecenderungan siswa yang kurang memperhatikan materi pembelajaran perlu disikapi oleh guru, dengan melakukan beberapa perbaikan dalam melaksanakan pembelajaran. Hal ini terlihat pada hasil belajar siswa pada nilai ulangan harian sebelumnya. Dalam hal ini dapat diupayakan dengan penerapan model pembelajaran yang sesuai yang dipadukan dengan media pembelajaaran yang tepat. Model pembelajaran iqro' yang dipadukan dengan media video adalah salah satu model pembelajaran dan media pembelajaran yang dapat digunakan. Model iqro' adalah suatu model pembelajaran yang mengajak siswa untuk aktif mengeksplorasi lingkungan yang ada di sekitar siswa. Siswa diajak untuk aktif berkegiatan misalnya berfikir, merenung, berdiskusi, mengamati (Setyaningrum, 2007). Berdasarkan beberapa pertimbangan di atas, penulis berinisiatif untuk melakukan penelitian terkait model pembelajarn Iqro' berbantuan media video untuk meningkatkan hasil belajar siswa.

\section{Rumusan Masalah}

Bagaimanakah Peningkatan Hasil Belajar IPA Melalui Model Pembelajaran Iqro' berbantuan Media Video Pada Siswa Kelas VII A SMP Negeri 2 Amali Kabupaten Bone. 


\section{Metodologi penelitian}

Jenis penelitian yang digunakan penelitian tindakan kelas (classroom Action Research) yang terdiri dari empat tahap yakni perencanaan, pelaksanaan, observasi dan evaluasi dan refleksi. Tempat penelitian di SMP Negeri 2 Amali Kecamatan Amali Kabupaten Bone Tahun Pelajaran 2018/2019. Penelitian ini dilaksanakan pada bulan April Tahun Ajaran 2018/2019.

\section{Prosedur Penelitian}

Prosedur penelitian tindakan kelas ini dilaksanakan dalam dua siklus yaitu siklus I dan siklus II. Siklus I dan II dilaksanakan dalam 3 kali pertemuan dan setiap akhir siklus diberikan evaluasi. Kegiatan- kegiatan pada siklus II merupakan perbaikan dari siklus I jika masih terdapat sesuatu yang tidak diharapkan. Pada masing - masing siklus terdiri atas tahap perencanaan tindakan, tahap pelaksanaan, tahap observasi dan evaluasi, serta tahap refleksi. Pada tahap perencanaan tindakan peneliti bersama guru mata pelajaran melakukan observasi dan diskusi awal untuk membahas masalah-masalah dalam kelas yang akan dipecahkan, kemudian menelaah materi pelajaran kelas VII untuk semester genap. Mempersiapkan perangkat pembelajaran berupa rencana pelaksanaan pembelajaran (RPP) yang akan digunakan selama proses belajar mengajar berlangsung. Memilih media pembelajaran yang sesuai dengan materi yang akan diajarkan dan model yang akan diterapkan. Membuat instrument pengamatan berupa lembar observasi untuk mengetahui aktivitas siswa saat proses pembelajaran berlangsung dengan berdasar pada langkah-langkah model yang diterapka merancang dan membuat lembar kerja berdasarkan indikator dan tujuan pembelajaran, selanjutnya membuat tes hasil belajar untuk mengukur hasil belajar siswa. Tahap pelaksanaan tindakan meliputi kegiatan pembelajaran yang dilakukan di dalam kelas, yakni Guru mengucapkan salam, mengecek kelas serta kehadiran siswa selanjutnya membuka pelajaran. Guru menuliskan tujuan pembelajaran yang ingin dicapai dan memberikan apersepsi untuk memotivasi siswa Guru kemudian memberi kesempatan kepada beberapa siswa untuk menjawab, kemudian mengarahkan siswa kepada langkah-langkah dari model pembelajaran Iqro'. Setelah itu, Guru memberikan pelatihan mandiri kepada siswa dengan cara membagikan lembar kerja, selanjutnya memberikan kesempatan kepada siswa untuk mengerjakan lembar kerja dari guru. Guru mengumpulkan pekerjaan siswa, kemudian guru dan siswa bersama sama membahas lembar kerja tersebut. Setelah itu, guru memberikan kesempatan kepada siswa untuk menanyakan materi yang kurang dipahami. Guru mengarahkan siswa untuk menarik kesimpulan tentang materi yang telah dipelajari. Guru menyampaikan kepada siswa agar mempelajari materi selanjutnya di rumah, kemudian guru menutup pelajaran. Tahap observasi dan evaluasi, meliputi pengamatan terhadap aktivitas siswa pada saat pembelajaran berlangsung dengan menggunakan lembar observasi yang telah dibuat dan pemberian evaluasi di akhir siklus. Tahap refleksi, dilakukan untuk menemukan masalah yang mungkin terjadi pada siklus I untuk selanjutnya menjadi acuan untuk perencanaan tindakan yang dilakukan di siklus II.

\section{Indikator Keberhasilan}

Indikator yang menunjukkan keberhasilan pelaksanaan penelitian yang dilakukan adalah hasil Belajar Siswa setelah diajar dengan menggunakan model pembelajaran Iqro' berbantuan media video mencapai rata-rata skor $\geq 70$ tiap siklus dan ketuntasan belajar siswa secara perorangan minimal mencapai $80 \%$ secara klasikal. 
Peningkatan Hasil Belajar IPA melalui Model Pembelajaran Iqro' dengan Berbantuan Media Video pada Siswa Kelas VII A SMP p-ISSN 2621-5527 Negeri 2 Amali Kabupaten Bone

e-ISSN 2621-5535 (hlm. 124-133)

\section{Sampel Penelitian}

Subjek dalam penelitian ini adalah siswa kelas VII A SMP Negeri 2 Amali Kecamatan Amali Kabupaten Bone Tahun Pelajaran 2018/2019 dengan jumlah siswa 18 orang. Keadaan subjek penelitian disajikan pada tabel berikut:

Tabel 1 Subjek Penelitian

\begin{tabular}{|c|c|c|c|}
\hline \multirow{2}{*}{ Kelas } & \multicolumn{2}{|c|}{ Jenis kelamin } & Jumlah \\
\hline \multirow{2}{*}{ VII A } & Laki-laki & Perempuan & 18 \\
\cline { 2 - 3 } & 10 & 8 & \\
\hline
\end{tabular}

Sumber: SMP Negeri 2 Amali Kabupaten Bone Tahun Pelajaran 2018/2019

Penelitian tindakan kelas ini dilaksanakan sebanyak dua siklus. Penelitian ini terdiri dari empat tahap yaitu perencanaan, pelaksanaan, pengamatan dan evaluasi serta refleksi. Tiap siklus dilakukan perubahan sesuai dengan tujuan yang ingin dicapai. Secara rinci pelaksanaan penelitian untuk dua siklus ini yaitu siklus I sebanyak tiga kali pertemuan dan siklus II sebanyak tiga kali pertemuan. Instrument yang digunakan adalah lembar observasi dan tes hasil belajar. Data mengenai aktivitas diperoleh dengan menggunakan lembar observasi yang terdiri dari beberapa kegiatan sesuai dengan langkah-langkah model pembelajaran Iqro'. Pengisian lembar observasi diisi pada saat proses pembelajaran berlangsung. Sedangkan untuk memperoleh data hasil belajar menggunakan tes berupa multiple choice berjumlah 25 nomor.Setiap pertanyaan dilengkapi 4 pilihan. Nilai untuk setiap jawaban yang benar adalah empat, sedangkan jawaban yang salah mendapatkan nilai 0 .

\section{Analisis Data}

Pengolahan data menggunakan analisis statistik deskriptif. Untuk mengolah data hasil belajar dalam penelitian ini, maka langkah pertama yang harus dilakukan yakni merata-ratakan semua skor hasil belajar dengan menggunakan SPSS v25, membuat tabel statistik data tes hasil belajar yang meliputi subyek penelitian, nilai ideal, nilai minimum, nilai maksimm, nilai ratarata, dan median, serta membuat tabel kategori berdasarkan nilai rata-rata dalam kategori yaitu sangat tinggi, tinggi, sedang, rendah, dan sangat rendah. Langkah terakhir adalah membuat tabel ketuntasan hasil belajar untuk mengetahui indikator keberhasilan telah tercapai atau belum.

Tabel 2. Skala Kualifikasi Hasil Belajar Siswa

\begin{tabular}{|c|c|}
\hline Nilai & Kategori \\
\hline $89-100$ & Sangat tinggi \\
\hline $77-88$ & tinggi \\
\hline $65-76$ & sedang \\
\hline $40-64$ & rendah \\
\hline $0-39$ & sangat rendah \\
\hline
\end{tabular}

Sumber: Kemendikbud 2017

Setelah dimasukkan ke dalam tabel pengkategorian, maka langkah selanjutnya adalah dengan membuat tabel klasifikasi tingkat ketuntasan belajar siswa. 
p-ISSN 2621-5527

e-ISSN 2621-5535
Peningkatan Hasil Belajar IPA melalui Model Pembelajaran Iqro' dengan Berbantuan Media Video pada Siswa Kelas VII A SMP Negeri 2 Amali Kabupaten Bone (hlm. 124-133)

Tabel 3. Klasifikasi Ketuntasan Belajar Siswa

\begin{tabular}{|c|c|}
\hline Nilai & Kategori \\
\hline $70-100$ & Tuntas \\
\hline $0-69$ & Tidak Tuntas \\
\hline
\end{tabular}

\section{Hasil Penelitian}

\section{Hasil Belajar}

Data hasil belajar siswa kelas VII A SMP Negeri 2 Amali pada siklus I dan II berbentuk tes pilihan ganda yang dilaksanakan tiap akhir siklus menunjukkan hasil yang meningkat. Adapun deskriptif nilai hasil belajar IPA siswa pada siklus I dapat dilihat pada tabel di bawah ini.

Tabel 4. Statistik Nilai Hasil Belajar IPA Siswa pada Siklus I dan Siklus II

\begin{tabular}{|c|c|c|}
\hline \multirow{2}{*}{ Statistik } & \multicolumn{2}{|c|}{ Nilai statistik } \\
\cline { 2 - 3 } & Siklus I & Siklus II \\
\hline Subjek Penelitian & 18 & 18 \\
\hline Nilai Ideal & 100 & 64 \\
\hline Nilai Minimum & 52 & 96 \\
\hline Nilai Maksimum & 88 & 85,11 \\
\hline Nilai Rata-Rata & 70,78 & 84 \\
\hline Median & 70 & 100 \\
\hline
\end{tabular}

Sumber: Data Olahan 2019

Selanjutnya jika penguasaan siswa di atas dikelompokkan ke dalam lima kategori maka frekuensi dan presentase hasil belajar dapat dilihat pada tabel dibawah ini.

Tabel 5. frekuensi dan Persentase Nilai Hasil Belajar IPA Siswa Pada Siklus I dan Siklus II

\begin{tabular}{|c|c|c|c|c|c|}
\hline \multirow{2}{*}{ Interval } & \multirow{2}{*}{ Kategori } & \multicolumn{2}{|c|}{ Siklus I } & \multicolumn{2}{c|}{ Siklus II } \\
\cline { 3 - 6 } & & F & \% & F & \% \\
\hline $89-100$ & Sangat Tinggi & 0 & 0 & 6 & 33,33 \\
\hline $77-88$ & Tinggi & 6 & 33,33 & 10 & 55,56 \\
\hline $65-76$ & Sedang & 5 & 27,78 & 2 & 11,11 \\
\hline $40-64$ & Rendah & 7 & 38,89 & 0 & 0 \\
\hline $0-39$ & Sangat Rendah & 0 & 0 & 0 & 0 \\
\hline
\end{tabular}

Data mengenai ketuntasan belajar dapat dilihat berdasarkan daya serap siswa. Apabila daya serap siswa dikelompokkan ke dalam kategori tuntas dan tidak tuntas, maka diperoleh frekuensi dan persentase ketuntasan belajar pada siklus I dan siklus II dapat dilihat pada berikut:

Tabel 6. Deskriptif Ketuntasan Belajar Siswa pada Siklus I dan Siklus II

\begin{tabular}{|c|c|c|c|c|c|}
\hline \multirow{2}{*}{ Kategori } & \multirow{2}{*}{ Nilai } & \multicolumn{2}{|c|}{ Siklus I } & \multicolumn{2}{c|}{ Siklus II } \\
\cline { 3 - 6 } & & $\mathbf{f}$ & $\mathbf{\%}$ & $\mathbf{f}$ & $\mathbf{\%}$ \\
\hline Tuntas & $70-100$ & 7 & $38,89 \%$ & 16 & $88,89 \%$ \\
\hline Tidak tuntas & $0-69$ & 11 & $61,11 \%$ & 2 & $11,11 \%$ \\
\hline
\end{tabular}


Peningkatan Hasil Belajar IPA melalui Model Pembelajaran Iqro'

dengan Berbantuan Media Video pada Siswa Kelas VII A SMP

p-ISSN 2621-5527

Negeri 2 Amali Kabupaten Bone

e-ISSN 2621-5535

(hlm. 124-133)

\section{Pembahasan}

Berdasarkan pada tabel 4 dan 5 terlihat adanya peningkatan hasil belajar siswa kelas VII A SMP Negeri 2 Amali melalui model pembelajaran Iqro' berbantuan media video yang dilakukan dalam dua siklus. Hasil penelitian menunjukkan bahwa nilai hasil belajar siswa kelas VII A SMP Negeri 2 Amali pada siklus I mencapai rata-rata 70,78 dalam artian berada pada kategori sedang. Hasil yang diperoleh dari siklus I masih kurang maksimal hal ini di karenakan siswa belum beradaptasi dengan model pembelajaran Iqro' dengan media video. Pada awal pelaksanaan pembelajaran dengan menggunakan model pembelajaran Iqro' berbantuan media video, siswa masih terlihat canggung untuk aktif dalam proses pembelajaran. Hal ini disebabkan model pembelajaran dengan media video belum terbiasa bagi siswa. Pelaksanaan pembelajaran menggunakan model pembelajaran Iqro' berbantuan media video ini yakni guru menjelaskan tujuan dan pentingnya materi yang akan dipelajari untuk mendorong siswa lebih berperan aktif dan menghubungkan materi yang akan dipelajari dengan kehidupan sehari-hari. Secara spesifik penerapan model ini dengan cara Iqro' (membaca) yang dilandasi dengan nilai IMTAQ (iman dan taqwa), dalam memahami lingkungan sekitar siswa, sehingga timbul kaitan antara belajar IPA dengan potensi membangun keyakinan akan kebesaran Tuhan terhadap ciptaan-Nya. Akhirnya pada pertemuan berikutnya dengan penerapan model pembelajaran Iqro' berbantuan media video siswa sudah memperlihatkan perubahan sedikit demi sedikit meskipun masih ditemukan kekurangan antara lain, jiwa keagamaan masih kurang dikenalkan sejak dini, siswa kurang percaya diri dalam menyampaikan pendapat serta kurangnya keberanian untuk bertanya dan menjawab pertanyaan. Sejalan dengan penelitian yang dilakukan oleh Adhayani dan Dewi (2015), mengungkapkan bahwa media pembelajaran merupakan alat yang berfungsi untuk menyampaikan pesan pembelajaran, dimana media yang digunakan adalah media multimedia yang disandingkan dengan model pembelajaran Iqro'. Hasil penelitian menunjukkan bahwa media yang digunakan membantu dalam berkomunikasi dan memotivasi pengguna agar lebih efektif dalam melakukan proses pembelajaran. Dengan konsep multimedia, pembelajaran Iqro' dapat memberikan tampilan visual yang lebih menarik dan tidak terkesan monoton.

Model iqro' merupakan suatu model pembelajaran yang mengajak siswa untuk aktif mengeksplorasi lingkungan yang ada di sekitar siswa. Siswa diajak untuk aktif berkegiatan misalnya berfikir, merenung, berdiskusi, mengamati. Model pebelajaran Iqro' memiliki tiga sintaks yaitu eksplorasi, konseptualisasi dan komunikasi (Setyaningrum 2007). Penerapan model pembelajaran ini masih terasa kaku bagi siswa, sehingga hasil belajarnya juga belum optimal. Menurut Ridlo (2005), langkah-langkah model pembelajaran Iqro' terorganisasi dalam tiga langkah yakni, pertama adalah Fase Eksplorasi dimana fase ini menumbuhkan pemahaman hakikat ketuhanan dimulai dengan menanamkan rasa percaya adanya sesuatu yang dapat deteladani dalam belajar dan memotivasi peserta didik dengan sifat ketuhanan, seperti kejujuran, keadilan, kebijaksanaan, sosial, kasih sayang, dan sebagainya untuk memberi tujuan yang sesuai objek yang akan dipelajari. Selain itu, menumbuhkan pencarian hakikat manusia dimulai dengan menumbuhkan rasa tidak percaya yang dapat menimbulkan hipotesis dan mendorong peserta didik untuk dapat menemukan jawaban dengan berbagai cara, seperti pemgamatan, percobaan, membaca, dan sebagainya. Kedua, fase konseptualisasi yakni memotivasi kembali bahwa jawaban peserta didik benar atas hipotesisnya dengan dilandasi sifat ketuhanan. Ketiga, fase komunikasi dimana siswa melaporkan jawaban dalam bentuk tulisan, gambar, karya tulis lain serta mempresentasikan kepada teman atau orang lain.

Menyikapi berbagai masalah yang terjadi pada siklus I, maka perbaikan yang dilaksanakan pada siklus II. Perbaikan tersebut antara lain menumbuhkan pemahaman hakikat ketuhanan yang dimulai dengan menanamkan rasa percaya adanya sesuatu yang dapat diteladani dalam belajar, menumbuhkan pencarian hakikat manusia dimulai dengan menumbuhkan rasa tidak percaya yang dapat menimbulkan hipotesis dan mendorong peserta 
didik untuk dapat menemukan jawaban dengan berbagai cara seperti pengamatan, percobaan, dan membaca, Siswa diharapkan untuk membaca dengan cermat dan mengembangkan sikap kritisnya, mendorong siswa untuk lebih percaya diri dalam menyampaikan pendapat dihadapan teman-temannya.

Pada siklus II terjadi peningkatan nilai rata-rata menjadi 85,11 berada pada kategori tinggi. Peningkatan hasil belajar yang diperoleh siswa mengindikasikan bahwa proses belajar mengajar menggunakan model pembelajaran Iqro' berbantuan media video memberikan konstribusi positif terhadap prestasi akademik siswa sekaligus meningkatkan jiwa keagamaan siswa sehingga siswa lebih mudah memahami materi IPA khususnya materi biologi di kehidupan sehari-hari yang dikaitkan dalam Al-Qur'an. Selain itu, ada indikasi bahwa nilai hasil belajar siswa meningkat jika terjadi peningkatan kemampuan mengajar guru, dalam menerapkan model pembelajaran yang tepat pada setiap proses pembelajaran. Pada kegiatan pengamatan langsung ini siswa juga diharapkan dapat mengkaji alam untuk memperoleh ilmu sekaligus memperoleh pemahaman akan kekuasaan Tuhan. Penerapan model pengamatan langsung terhadap objek belajar dapat memotivasi siswa menjadi lebih tertarik pada bahasan yang sedang dipelajari karena dikaitkan dengan hal- hal nyata yang terjadi dalam kehidupan sehari-hari .

Keberhasilan peningkatan hasil belajar siswa kelas VII A melalui model pembelajaran Iqro' berbantuan media video memberi gambaran yaitu model pembelajaran Iqro' merupakan suatu model pembelajaran yang tergolong baru bagi siswa dan belum pernah di dapatkan sebelumnya sehingga memberi pembelajaran yang baru serta dengan adanya media video dapat menumbuhkan belajar siswa lebih menarik perhatiannya dalam proses pembelajaran. Selain itu, dapat menumbuhkan pemahaman hakikat ketuhanan siswa mulai dengan menanamkan rasa percaya adanya sesuatu yang dapat diteladani dalam belajar. Memotivasi siswa dengan sifat ketuhanannya seperti kejujuran, keadilan, kebijaksanaan, sosial, kasih sayang untuk member tujuan sesuai objek yang di pelajari. Dapat menumbuhkan pencarian hakikat manusia dimulai dengan menumbuhkan rasa tidak percaya yang dapat menimbulkan hipotesis dan mendorong peserta didik untuk dapat menemukan jawaban dengan berbagai cara, seperti pemgamatan, percobaan, membaca. Serta dapat menumbuhkan rasa percaya diri siswa menyampaikan pendapat di depan teman- temannya. Persepsi siswa pada indikator sistem nilai terjadi peningkatan skor rerata, sebelum diterapkan model pembelajaran iqro' sudah dalam kategori baik setelah penerapan model pembelajaran iqro' meningkat menjadi kategori baik sekali dalam artian siswa menilai model pembelajaran iqro' bermanfaat dan baik untuk diterapkan dalam pembelajaran IPA karena dapat menambah wawasan dan meningkatkan rasa syukur terhadap Tuhan yang Maha Esa (Nurasni 2015).

Hal ini terlihat bahwa model pembelajaran Iqro' berbantuan media video dapat mendorong siswa lebih berperan aktif dan mampu memahami serta menghubungkan materi pelajaran dengan kehidupan nyata disekitarnya dengan cara iqro' (membaca), yang dilandasi dengan nilai IMTAQ (imam dan taqwa) dalam memahami lingkungan sekitar siswa sehingga timbul kaitan antara belajar IPA dan potensi membangun keyakinan akan kebesaran Tuhan terhadap ciptaan-Nya. Proses uji coba pembelajaran secara terintegrasi IPTEK dan IMTAQ dapat mengubah pengetahuan dan penguasaan materi oleh siswa dengan sangat bermakna.

Selain model pembelajaran, media yang digunakan juga sangat membantu dalam meningkatkan hasil belajar. Selain hasil belajar, media video dapat meningkatkan minat belajar, memotivasi dalam proses pembelajaran, serta siswa memperoleh gambaran secara nyata mengenai konsep yang dikaji dan menjadi suatu kelebihan tersendiri, karena peserta didik secara tidak langsung diajak memahami konsep secara nyata terus menerus dan melatih kemampuan diri demi menuju kearah yang lebih baik serta membuat siswa lebih mandiri lagi dalam proses pembelajaran (Wisada, I komang, I Wayan, 2019). Hal ini dikarenakan, media video yang disajikan berisi pesan dan mempunyai unsur gerak sehingga menarik perhatian dan 
Peningkatan Hasil Belajar IPA melalui Model Pembelajaran Iqro'

dengan Berbantuan Media Video pada Siswa Kelas VII A SMP

p-ISSN 2621-5527

Negeri 2 Amali Kabupaten Bone

e-ISSN 2621-5535

(hlm. 124-133)

motivasi siswa dalam pembelajaran. Sejalan dengan penelitian yang dilakukan oleh Purwanto dan Rizki (2015), menunjukkan bahwa video pembelajaran sangat layak digunakan, dimana video merupakan sumber belajar yang menarik dan memiliki banyak gambar serta dilengkapi dengan visualisasi, dalam hal ini beliau mengembangkan video pembelajaran matematika berbasis kontekstual. Penelitian lain yang terkait dengan media video juga mengemukakan bahwa penggunaan media tersebut mampu mengefektifitaskan waktu dan ruang. Disamping itu, media video dapat menampilkan objek yang terlalu kecil, besar, atau bahkan mampu menjelaskan sesuatu yang bersifat abstrak (Kairani, sutisna, \& Slamet, 2019). Penggunaan multimedia dalam pembelajaran dapat meningkatkan pemahaman konsep materi bila dibandingkan dengan menggunakan media lain (charta, torso, dan model). Selain itu pembuatan suatu program multimedia sangat fleksibel, sehingga guru dapat berkreasi atau dapat juga mencari sumber-sumber media belajar yang semakin lengkap tersedia. Penggunaan media atau alat bantu disadari oleh banyak praktisi pendidikan bahwa itu sangat membantu aktivitas proses pembelajaran, terutama meningkatkan prestasi belajar siswa (Gowasa, fauziyah, \& Retno, 2019).

Model pembelajaran ini bisa dijadikan sebagai bahan pertimbangan untuk digunakan model pembelajaran yang mampu meningkatkan hasil belajar siswa, apalagi dengan kemampuan siswa yang masih terbatas khususnya pemahaman IPA, Siswa memberikan respon dan partisipasi yang sangat baik pada saat berlangsungnya pembelajaran yang menerapkan pengintegrasian nilai agama dalam pembelajaran biologi (Sutiani 2010). Berdasarkan data hasil belajar siswa yang aktif dalam pembelajaran cenderung memiliki hasil belajar yang baik begitu pula sebaliknya sehingga penelitian ini dihentikan pada siklus II karena telah mencapai indikator keberhasilan yang telah ditentukan sebesar $80 \%$ secara klasikal yaitu dengan siswa yang tuntas mencapai 88,89\%.

\section{Kesimpulan}

Berdasarkan hasil analisis dan pembahasan maka dapat disimpulkan bahwa melalui model pembelajaran Iqro' dengan media video dapat meningkatkan hasil belajar siswa kelas VII A SMP Negeri 2 Amali Kabupaten Bone khususnya pada materi pencemaran lingkungan. Hal ini dapat dilihat dari nilai rata-rata hasil belajar siswa yang mengalami peningkatan dari siklus I sebesar 70,78 sedangkan nilai rata - rata siklus II sebesar 85,11 dengan selisih 18,11 . Selain itu ketuntasan hasil belajar siswa juga meningkat terlihat pada jumlah siswa yang tuntas pada siklus I sebanyak 11 siswa $(61,11 \%)$ dan naik pada siklus II menjadi 16 (88,89\%) telah melampaui indikator keberhasilan yang telah ditetapkan secara klasikal yaitu $80 \%$.

\section{Terima Kasih}

Secara khusus penulis menyampaikan ucapan terima kasih kepada pembimbing yang telah memberi arahan, bimbingan, dan motivasi yang sangat berharga bagi penulis. Kepala Sekolah SMP Negeri 2 Amali Kabupaten Bone, beserta guru dan segenap stafnya atas bimbingan dan sarannya pada saat penelitian berlangsung. Terima kasih.

\section{Referensi}

Adhayani, A., \& Dewi, T. (2015). Pengembangan Sistem Multimedia Pembelajaran Iqro' Menggunakan Metode Luther. Jurnal Algoritma (online). 12 (1). httpp://jurnal.sttgarut.ac.id.

Cheppy Riyana. (2007). Pedoman Pengembangan Media Video. Jakarta. P3AI UPI. 
Gowasa, S., Fauziyah, H., \& Retno, D.S. (2019). Perbedaan Penggunaan Media Power Point dan Video Pembelajaran terhadap Kemampuan Berpikir Tingkat Tinggi dan Retensi Memori Siswa pada Mata Pelajaran IPA di Kelas V SD, Jurnal Tematik, 9 (1).

Karyani,Lilis. (2007). Meningkatkan Pemahaman Siswa Menggunakan Pendekatan Jelajah Alam Sekitar (JAS) dengan Model Pembelajaran Iqro' PadaMateri Prinsip-prinsip Klasifikasi,Virus Dan Monera di Man 2 Semarang. Skripsi. Semarang. Universitas Negeri Semarang.

Kemendikbud. (2017). Pedoman Kurikulum 2013 untuk SMP. Jakarta. kemendikbud

Khairani, M.,Sutisna, \& Slamet, S. (2019). Studi Meta - analisis Pengaruh Video Pembelajaran terhadap Hasil Belajar Peserta Didik, Jurnal Biolokus, 2 (1), 158 - 166.

Mayer, Richard E. \& Moreno, Roxana. (2012). Animation as an aid Multimedia Learning, Educational Psicology Review.

Purwanto, Y., \& Rizki, S. (2015). Pengembangan Bahan Ajar Berbasis Kontekstual pada Materi Himpunan Berbantu Video Pembelajaran. AKSIOMA Journal of Mathematic Education, 4(1), 67-77. http://doi.org./10.24127/ajpm.v4il.95

Ridlo, S. (2005). Pendekatan Jelajah Alam Sekitar. Disampaikan dalam Semlok Pengembangan Kurikulum dan Desain Studi Pendidikan Biologi dengan Pendekatan Jelajah Alam Sekitar (JAS). Semarang. Universitas Negeri Semarang

Setyaningrum, Nurina. (2007). Penerapan Model Pembelajaran Iqro' Guna Meningkatkan Ketercapaian Kecakapan Hidup Siswa pada Pembelajaran Prinsip-Prinsip Klasifikasi,Virus, dan Monera pada Siswa Kelas X-A Semester 1 MA Al-Asror Semarang. Skripsi. Semarang. Universitas Negeri Semarang.

Sutiani, Sri. (2010). Integrasi Nilai Keislaman dan Pemahaman Materi Biologi dengan Pendekatan Contextual Teaching and Learning.Yogyakarta. Skripsi.

Wisada, P.D., I Komang, S., \& I Wayan, I.Y.S. (2019). Pengembangan Media Video Pembelajaran Berorientasi Pendidikan Karakter. Jurnal of Education Technology, 3 (3), 140 - 146.

\begin{tabular}{|c|c|}
\hline Sri Wahyuni & $\begin{array}{l}\text { Dosen STKIP Muhammadiyah Bone } \\
\text { Email: alifaxwahyuni68@gmail.com }\end{array}$ \\
\hline Lita Citra & $\begin{array}{l}\text { Mahasiswa STKIP Muhammadiyah Bone } \\
\text { Email : citralitamus01@gmail.com }\end{array}$ \\
\hline
\end{tabular}

